\title{
Prospects and Challenges of Crowdfunding as an Alternative Funding Option in Nigeria
}

\author{
Abdulmajeed M. R. Aderemi ${ }^{1 *}$, Sri Maulida ${ }^{2}$, Abdullateef Abdulqadir \\ Maikabara $^{3}$ \\ Faculty of Business and Management, Universiti Sultan Zainal Abidin, Malaysia ${ }^{1}$ \\ Faculty of Economic and Business, Universitas Lambung Mangkurat, Indonesia ${ }^{2}$ \\ Institute of Islamic Banking and Finance, International Islamic University Malaysia ${ }^{3}$
}

Submitted: 1 September, 2020; Accepted: 21 July, 2021; Published: 26 July, 2021

\begin{abstract}
This study aims to review the concept, prospects, and challenges of crowdfunding in Nigeria. Furthermore, it adopts a library-based concept in which secondary sources are relied on data collection using descriptive and deductive approaches of analysis. The results showed that Nigeria has the potential of becoming the hub center of crowdfunding in Africa. However, various challenges are facing the growth of this platform as a means of financing. These include the issues of regulation, lack of adequate awareness, as well as fraud and corruption. Furthermore, this study recommends the need for adequate awareness about crowdfunding and the regulation to ensure its functionality. It also offers additional literature as a means of financing, especially from the Nigerian context.
\end{abstract}

Keywords: crowdfunding, funding option, prospect, challenges, Nigeria. 


\section{INTRODUCTION}

Crowdfunding has grown into a successful substitute and alternative for nontraditional financing practices in recent years (Schwienbacher \& Larralde, 2012). Typically, it is an unconventional alternative method of soliciting for funds from a huge group of people with the help of the internet (Ordanini, Miceli, Pizzetti, \& Parasuraman, 2011). The 2008 global financial crisis caused challenges for businesses to acquire loans from banks because of strict requirements, limited amounts offered and high-interest rates (Hendratmi, Sukmaningrum, Ryandono, \& Ratnasari, 2019). Therefore, this financial crisis together with the evolution and globalization of social media and technology has made the evolvement of crowdfunding easier to use as a means of financing (Schwienbacher \& Larralde, 2012), and many countries have been utilizing this funding alternative. The industry report by Massolution (2015) stated that North America is the largest region with a crowdfunding market. Furthermore, this growth has also been recorded in Europe and some Asian regions. In contrast, there is a slow growth of crowdfunding in African regions.

The mechanism of increasing the growth of crowdfunding in Nigeria as a developing country is through gradual penetration. A report shared by Afrikstart (2015) showed that at the end of 2015, there were 57 crowdfunding platforms across Africa, with South Africa leading with 21 platforms. This was followed by Nigeria and Egypt with 9 and 5 platforms respectively. However, the overall crowdfunding market for Africa-based platforms as of then was estimated to be $\$ 32.3 \mathrm{~m}$, and this was less than $0.1 \%$ of the total activity around the globe. Out of this estimated fund, $\$ 30.8 \mathrm{~m}$ was raised by South Africa's local platform, followed by Egypt and Nigeria with $\$ 842,000$, and $\$ 314,445$ respectively. Recently, different kinds of crowdfunding platforms have come into existence in Nigeria to serve business financial needs. These platforms provide a far-reaching service in various sorts of activities which include charity, farming, and raising funds for the newly born business. However, there are still some challenges hindering the development of the crowdfunding industry in Nigeria. These include lack of regulation, awareness, and understanding, fraud, and corruption which is endemic in the country.

\section{The Concept of Crowdfunding}

For the last decade, crowdfunding has been thriving as an opportunity provider for businesses, charitable organizations, and individuals. It raises money from a large crowd of investors or contributors to provides for a variety of projects such as education, startups, and arts (Schwienbacher \& Larralde, 2012). Ordanini et al., (2011) defined it as "an activity attempted to raise fund for a new proposed project by gathering little to medium-size speculation from a few other individuals". Conceptually, the definition provided was later 
refined by Schwienbacher and Larralde (2012), where it was defined as an internet mode of funding by the public to the capital or entrepreneurs that are seeking investment for the motive of expecting reward or pure charity. This definition showed that the motive of its investment is not only to make a profit but also for the pleasure or fun of doing the particular task.

Moreover, the idea and utilization of crowdfunding are developing and being utilized in progressively inventive ways. The basic elements are centered around the intensity of the crowd, the technology, and capital financing, which permit numerous little endeavors to accumulate into a huge financial related result (Aderemi \& Ishak, 2020a; Ishak, Kamaruddin, \& Aderemi, 2021; Ishak \& Rahman, 2021). However, the crowdfunding procedure depends vigorously on technology, both in terms of the sites for the presentation and the social media that facilitates the information of its spread. In addition, crowdfunding can be used for advertising or promoting one's market, as well as generating interest for new projects in the primary stage of development (Mollick, 2014). Awareness about a task can be created through social media to build up a crowd of interested parties willing to contribute or invest (Hollander \& Greene, 2015).

There are four models of crowdfunding according to Massolution (2012): (1) Donation-based crowdfunding (2) Reward-based crowdfunding (3) Lending-based crowdfunding (4) Equity-based crowdfunding. Donation-based crowdfunding is a mechanism in which the collection of funds occurs through the internet for philanthropic, social, or other motives without expecting any compensation in return (monetary or not) (Aderemi \& Ishak, 2020b). Reward-based crowdfunding is a model where investors or backers receive an appreciation for financing an initiative as a token reward such as receiving acknowledgment, gift, or being provided with the products supported (Thaker, Thaker, \& Pitchay, 2018). Meanwhile, lending-based or loan-based crowdfunding has a similar concept to the borrowing of money in a traditional way. It is only different as an internet-enabled platform where lenders or investors choose to lend money to the borrowers or founders in exchange for lower interest which is set by the platform (Thaker, Mohammed, Duasa, \& Abdullah, 2016). Equity-based crowdfunding is an online platform in which funders obtain benefits (financial return) in the form of fundraiser's equity-based revenue or profit-share arrangements (Wilson \& Testoni, 2014).

Historically, the first crowdfunding occurrence was traced back to the construction of the pedestal of the Statue of Liberty when transported to the United State as a diplomatic gift from the government of France. Unfortunately, the United State government was incapable to come up with the capital of $\$ 250,000$ for a granite plinth for the statue. The lack of funds incited Joseph Pulitzer a famous publisher to launch a fundraising campaign in a newspaper 
(Abdullah, 2016). In 1997 the first-ever online crowdfunding and the second in history came into occurrence according to Wahjono, Marina, and Widayat (2015), when Rock band Marillion (The British music band) release the seventh album and were not able to afford to tour. Their American fans arranged and raised $\$ 60,000$ by using fledgling internet for the band to travel to the US and play there.

In 2001, the first crowdfunding website appeared which was the "Artistshare" platform(Amuna, Al Shobaki, Naser, \& El Talla, 2017). The phenomenon is older than the term "crowdfunding", and according to Meric, Maque, and Brabet (2016), the word was invented by Michael Sullivan in August 2006 when inaugurating the "fundavlong" (videoblog incubator) project and ever since then it has become popular. Subsequently, the global financial crisis in 2008 coupled with the evolution and globalization of social media as well as technology has made the evolvement of crowdfunding easier to use as a means of financing. Furthermore, Massolution (2015) reported that over 1,250 platforms worldwide have emerged on the market and the industry has achieved about \$34bn, with a predictable growth of up to \$96bn in 2020.

\section{METHOD}

This study aims to determine the prospects and challenges of crowdfunding as an alternative funding option for businesses in Nigeria. It employs library-based methods through descriptive and deductive approaches to reviews and analyses various works related to literature. Furthermore, it recommends the need for creating an enabling environment (i.e. the regulation, proper education, as well as awareness) for the effectiveness of crowdfunding as a powerful tool for economic growth in developing countries. Crowdfunding platforms may help to kick-start organizations in Nigeria as a country of millions of young businesspersons, with a fast-growing population, which has a widespread mobile user and internet connectivity, together with strong social media usage and a great network of family and friends.

\section{RESULT AND DISCUSSION \\ Prospect of Crowdfunding in Nigeria}

Nigeria has positive features which in place make it potential to form an effective crowdfunding market in the West African country. These features include a large and fastgrowing population; widespread mobile users and internet connectivity; strong social media usage; a great network of family and friends, and thriving entrepreneurial prospects (Kazaure $\&$ Abdullah, 2018). Furthermore, the country has 126.08 million internet users in 2019, which was equivalent to $61.2 \%$ of the population rising from 92.7 million in 2015 , which was $51.1 \%$ 
as of then (IWS, 2019). Therefore, a large number of individuals can be reached through crowdfunding by potential entrepreneurs, and over the coming decades, these numbers are expected to grow tremendously.

In an interview conducted by CrowdfundInsider (2017) with the founder of a renowned study and consulting group in the alternative finance space "CrowdfundingHub" Wisse-Huiskes and Rondal Kleverlaan. The possibility of crowdfunding in Nigeria was discussed, where Kleverlaan, asserted that: "Nigeria is one of the fastest-growing emerging markets in the world and their financial infrastructure is ahead of others with innovative mobile banking apps. Crowdfunding is developing differently in emerging markets than in Europe and the US with high growth". Meanwhile, Wisse-Huiskes stated that there are multiple opportunities for the crowdfunding industry in Nigeria. The biggest ones are: Firstly, the strong social media usage and a great network of family and friends. With a fast-growing population of 179 million, where $84 \%$ have a mobile connection and over half of the population is already active on the Internet. Secondly, the entrepreneurial scene is expanding rapidly. Thirdly, the banking system is moving ahead of its counterparts in other emerging markets, and it provides a promising infrastructure for crowdfunding in Nigeria, with innovative mobile banking apps.

Crowdfunding is a fast-growing form of alternative finance benefiting from web-based technologies such as social media (Wahjono et al., 2015). On a global scale, the World Bank estimates that $\$ 93$ billion will be raised annually by 2025(World Bank, 2013). Meanwhile, the actual number of platforms in Nigeria is not known as of now. However, from the internet survey conducted, below is the table of the lists of some prominent local crowdfunding platforms that have sprouted in Nigeria recently and the type of model used. Notably, the majority of these platforms fund small businesses such as farming to nurture economic growth and employment.

Table 1. List of crowdfunding platforms in Nigeria

\begin{tabular}{llccc}
\hline No. & $\begin{array}{l}\text { Crowdfunding } \\
\text { Platforms }\end{array}$ & Website & Field & $\begin{array}{c}\text { Type of Crowdfunding } \\
\text { Platforms }\end{array}$ \\
\hline 1 & 234give & www.234give.com & NA & Donation-based \\
\hline 2 & Agropartnership & www.agropartnerships.co/ & $\begin{array}{c}\text { Smallholder } \\
\text { farmers }\end{array}$ & Agro -Investment \\
\hline 3 & ComFundMe & www.comfundme.com & $\begin{array}{c}\text { Social and } \\
\text { charity } \\
\text { project }\end{array}$ & Donation-based \\
\hline
\end{tabular}


Social and

4 Donate-ng www.donate-ng.com $\begin{aligned} & \text { charity } \\ & \text { project }\end{aligned}$

\begin{tabular}{llccc}
\hline 5 & E-Farms & www.efarms.com.ng/en & $\begin{array}{c}\text { Smallholder } \\
\text { farmers }\end{array}$ & Agro -Investment \\
\hline 6 & EZ -farming & www.ez -farming.com/ & $\begin{array}{c}\text { Smallholder } \\
\text { farmers }\end{array}$ & Agro -Investment \\
\hline 7 & FarmAgric & www.farmagric.com/ & $\begin{array}{c}\text { Smallholder } \\
\text { farmers }\end{array}$ & Agro -Investment \\
\hline 8 & FarmBuddy & www.farmbuddy.ng/ & $\begin{array}{c}\text { Smallholder } \\
\text { farmers }\end{array}$ & Agro - Investment \\
\hline 9 & FarmCrowdy & www.farmcrowdy.com & $\begin{array}{c}\text { Smallholder } \\
\text { farmers }\end{array}$ & Agro - Investment \\
\hline 10 & FarmFunded & www.farmfunded.com/ & $\begin{array}{c}\text { Smallholder } \\
\text { farmers }\end{array}$ & Agro - Investment \\
\hline 11 & Farmkart & www.farmkart.ng & $\begin{array}{c}\text { Smallholder } \\
\text { farmers }\end{array}$ & Agro - Investment
\end{tabular}

\begin{tabular}{|c|c|c|c|c|}
\hline 12 & FundanEnterprise & www.fundanenterprise.org & entrepreneurs & $\begin{array}{c}\text { Donation/lending/equity } \\
\text { based } \\
\end{array}$ \\
\hline 13 & Fundasolva & www.fundasolva.com & entrepreneurs & Reward/equity-based \\
\hline 14 & Funmilowo & www.funmilowo.com & $\begin{array}{l}\text { Creative } \\
\text { project }\end{array}$ & Donation-based \\
\hline 15 & GroupFarma & www.groupfarma.com.ng/ & $\begin{array}{c}\text { Smallholder } \\
\text { farmers }\end{array}$ & Agro-Investment \\
\hline 16 & Growsel & www.growsel.org & $\begin{array}{c}\text { Smallholder } \\
\text { farmers }\end{array}$ & Investment-Agro \\
\hline 17 & Imeela & www.imeela.com & $\begin{array}{l}\text { Entrepreneurs, } \\
\text { artists, charity }\end{array}$ & $\begin{array}{c}\text { Donation and Reward - } \\
\text { based }\end{array}$ \\
\hline \multirow[t]{2}{*}{18} & Menorah Farms & www.menorahfarms.com/ & Smallholder & Agro-Investment \\
\hline & & & farmers & \\
\hline 19 & NaijaFund & www.naijafund.com & $\begin{array}{l}\text { Entrepreneurs, } \\
\text { artists, charity }\end{array}$ & $\begin{array}{l}\text { Donation, Reward and } \\
\text { Lending-based }\end{array}$ \\
\hline 20 & Naturfund & www.naturfund.com & $\begin{array}{l}\text { Entrepreneurs, } \\
\text { artists, charity }\end{array}$ & $\begin{array}{c}\text { Equity, and Donation } \\
\text { based }\end{array}$ \\
\hline 21 & PayFarmer & www.payfarmer.com/ & $\begin{array}{c}\text { Smallholder } \\
\text { farmers }\end{array}$ & Agro-Investment \\
\hline 22 & PorkMoney & www.porkmoney.com/ & $\begin{array}{l}\text { Smallholder } \\
\text { farmers }\end{array}$ & Agro-Investment \\
\hline 23 & Pushandstart & www.pushandstart.com & Entrepreneurs & equity- and debt-based \\
\hline 24 & QuickRaiz & www.quickraiz.com & $\begin{array}{l}\text { Social and } \\
\text { charity } \\
\text { project }\end{array}$ & Donation-based \\
\hline 25 & SmartFarm & www.smartfarm.com.ng/ & $\begin{array}{l}\text { Smallholder } \\
\text { farmers }\end{array}$ & Agro-Investment \\
\hline 26 & Startcrunch & www.startcrunch.com & $\begin{array}{l}\text { Entrepreneurs, } \\
\text { artists, charity }\end{array}$ & Reward-based \\
\hline 27 & ThriveAgric & www.thriveagric.com & $\begin{array}{c}\text { Smallholder } \\
\text { farmers }\end{array}$ & Agro-Investment \\
\hline
\end{tabular}


Note: The actual number of crowdfunding platforms in Nigeria is unknown as of now. However, they were obtained from an internet survey conducted on various crowdfunding platforms.

\section{Challenges Facing Crowdfunding in Nigeria}

Crowdfunding is a mechanism that has taken over the corporate finance world and it is an effective, easy, and convenient way for an entrepreneur to raise funds. Owing to the vast and diverse human resources in Nigeria, it has the adequate potential of becoming one of the prevalent markets in the world. However, the adoption as a means of financing suggests the need to analyze the prominent challenges facing the newly embraced means of funding. This should be conducted to give recommendations for its accelerated growth and development in the country. Some of the identified challenges and their possible solutions are as follows:

\section{Regulatory Issues}

Different Crowdfunding platforms are emerging in the financial market in Nigeria as a means of financing including equity, lending reward, and donation. More platforms are coming up but unfortunately, the country does not have a comprehensive legal framework for its regulations (Kazaure \& Abdullah, 2018). This specific issue posed a very serious impediment to the progress of crowdfunding as a means of finance (Bolu, 2016). Furthermore, lack of regulation is the major challenge for crowdfunding (Kazaure \& Abdullah, 2018). Soreh (2017) stated that about ten indigenous platforms including Imeela, Naturefund, Funmilowo, Donateng, and more were closed down for a similar reason. In August 2016, Mounir Gwarzo, Nigeria Director-General of "SEC" (Securities and Exchange Commission) stated that the effectiveness of crowdfunding cannot be guaranteed owing to hindrance to conducting such activity as contained in the "CAMA" (Companies and Allied Matters Act) and "ISA" (Investments and Securities Act) Laws of the Federation of Nigerian (Kazaure \& Abdullah, 2018). However, in March 2020, SEC Nigeria (2020) proposed rules and made a demand for open comments on the draft. However, some of these rules in the proposed regulatory scheme rather than becoming a solution to boost and support crowdfunding as an alternative means of financing small and medium enterprises in Nigeria, it holds back some part of the contract.

The proposed rules created certain requirements to regulate crowdfunding, especially equity-based type. A crowdfunding platform is expected to be registered with the SEC and that such a platform requires to be operated by a registered intermediary body. Under this proposed rules, the right to cancel the registration of any platform is reserved for the SEC due to failure to meet up with the requirements of the rules such as a sum of 100 Million to operate a 
crowdfunding platform or lose out to control or keep up for a period of six months successively. Furthermore, the proposed rules specify the types of businesses that are permitted to solicit for funds through the crowdfunding platform. Precisely, it was stated in rule 2 that micro, small and medium enterprises (MSMEs) that are registered as a company should at least possess a minimum of two years operating track record before they can solicit for funds through a crowdfunding platform. Furthermore, companies lacking two years operating track record may also solicit for funds on the condition that they have an essential investor or a robust practical partner with a minimum of two years operating track record(SEC Nigeria, 2020).

The proposed rules set a limit to the amount that micro, small, and medium enterprises (MSMEs) can raise within a space of a year. It was stated in Rule 3(1) (b) that the maximum amount to be raised by a Medium enterprise shall not go beyond $\$ 100$ Million which is approximately equal to US\$263,157, and the amount to be raised by a Small enterprise shall not go beyond $\$ 70$ Million which is approximately equal to US\$184,210.00. Meanwhile, Microenterprise is not allowed to raise beyond $\$ 50$ Million which is approximately equal to US\$131,578.00. It also set a limitation to the maximum amount to be invested within a range of a year. Rule 3(3) stated that Investors are disallowed from investing more than $10 \%$ of their yearly income in a calendar year(SEC Nigeria, 2020).

It can be concluded that these rules are designed to protect investors from an unwanted stories. These new regulations permit to shut down some of those platforms that have been doing well over the year when they fail to raise the required amount of ( 100 Million) to operate a crowdfunding platform. However, they can choose to partner with another company since the partnership is the easiest route to avoid been shut down. SEC regulations will not affect them when they choose to operate only as technology providers to other registered bodies. Subsequently, the government should provide regulations that safeguard investors from fraud, duplicitous, dishonesty, and most important a stringent regulatory framework that will work for this means of financing.

It is worth mentioning that donation and rewards-based crowdfunding are not likely to be deeply affected by the proposed regulation draft since the backers neither have any return to share nor the financial profits from the business. However, Oguama (2020) suggested that donation-based crowdfunding should be controlled concerning companies in Nigeria to put a limitation in donating some specific cases like any political purpose. However, the proposed rules are still in drafts and up till now not launched. Therefore, the SEC can take a second look into the rules and make some amendments to favor the crowdfunding industry in Nigeria as well as to protect the investors like other countries. According to Oguama (2020), too much regulation can destroy or stifles innovation. This will help to strengthen investor protection with investment formation for entrepreneurs. 


\section{Lack of Adequate Awareness and Understanding}

Crowdfunding facilitates stress-free access to capital for businesses due to the use of the internet to promote and nurture the economy. Unfortunately, the mechanism is yet to be known by many people in Nigeria. In a study conducted by Soreh (2017) on the awareness of crowdfunding, it was stated that the awareness is very low and most of the respondents cannot identify or at least mention crowdfunding platforms in the country, and campaigns for entrepreneur activities are at its lowest flow. Practically, most of the successful crowdfunding's campaigns are mostly for charity like raising funds for sick or children, and instead of utilizing one of the established local crowdfunding platforms or portals, campaigners mostly go for the electronic media, specifically Television stations to raise funds for their cause with a chosen bank account(Lawal, 2019).

Berndt and Mbassana (2016) stressed that sufficient information and awareness about the crowdfunding concept is very important for entrepreneurs to know the working process and the potential outcomes. Meanwhile, Augustine (2019) stated that the rate of awareness about crowdfunding in Nigeria is very squat among its citizen and the maximum successful record for fundraising are for sick and it is conducted through television and radio. Finally, to overcome this challenge adequate awareness should be created through social media like Facebook, Twitter, and Instagram as well as spreading the awareness to friends and family by utilizing electronic media such as television and radio stations. Interestingly, social media played a significant role in increasing the awareness of crowdfunding(Mollick, 2014).

World Bank (2013), stressed that the measure of perception, which is influenced by education and can lead to broader acceptance and understanding of entrepreneurship should be attributed to the success of crowdfunding. However, the majority of Nigerians still have a wrong understanding or perception. In a study conducted by Okoyeuzu, Nwakoby, and Onwujekwe (2019) some respondent still believes that crowdfunding is a way government gives money to the SMEs. It was discovered that understanding crowdfunding as a way of raising money from family and friends or the government giving money to SMEs was influenced by occupation and education level. Gender was not significant for understanding crowdfunding to be a means of raising money from the public over the internet.

Therefore, greater education and knowledge should be delivered to the public to create a better understanding among the citizen. Crowdfunding is not only an alternative financial approach but also in some aspects provides better value propositions to the consumers because lack of adequate understanding and how it works will hamper the growth in Nigeria. Valančienè \& Jegelevičiūtè (2014) stated that the approaches used to promote crowdfunding in a country include model validation, encouraging the platforms, enhancement of campaigns, as well as appropriate and adequate education for entrepreneurs. 


\section{Fraud and Corruption}

Fraud refers to an act of depriving something of a person, which supposedly is entitled to such an individual. Verbally, it implies a deliberate action to gain an illegal advantage of someone(Ibrahim, 2019). Generally, fraud is one of the prominent issues posing a challenge to the growth of crowdfunding across the globe(Achsien \& Purnamasari, 2016). Additionally, it may manifest in various ways, from the funders or fundraisers, or outsiders. This is in correspondent with the study of Gabison (2015), where it was discovered that fraud constitutes the biggest threat to crowdfunding. However, Renwick and Mossialos (2017), asserted that even though fraud and money laundry constitute a big threat, the act is rare and does not significantly discourage people from participating in crowdfunding.

The issue of Nigeria when it comes to fraud is even more worrisome due to a large number of internet users. Ibrahim (2019) stated that the expansion of internet in the country has without a doubt come with unexpected fallout as a refuge for criminals. Therefore, the rate of internet fraud is very high, The NDIC (Nigeria Deposit Insurance Corporation) reported that the figure for internet (web-based) banking frauds increased from 316 in 2013 to 1,271 and 1,471 in 2014 and 2015, respectively(The Guardian, 2017). Evidence in 2016 showed that $43 \%$ of the overall monetary loss was accounted for cybercrime only due to fraud (Ibrahim, 2019). This is also together with the fact that corruption is rampant in the country.

Without a shred of doubt, once a country is labeled as a haven for fraud, potential investors will be cautious about investing through the internet due to the panic of being prey to cyber-attack. This will certainly undermine the development of crowdfunding as a means of financing in the country. However, Internet fraud cannot be simply eradicated but can be reduced. In other to minimize this crime to an insignificant level, there should be a call for an active collective and cooperative resolution between individuals, corporate associations and mostly the government. Furthermore, regulations should be provided to safeguard investors from fraud, duplicitous, dishonesty, and impose rigorous constraints concerning cybercrime that poses a threat to the business in Nigeria. Crowdfunding platforms are also indebted to create legitimate notices to their customers in conformity with the guidelines and measures prescribed by the governments.

\section{Issue of Trust and Transparency}

On a global scale, trust is one of the most important factors influencing the success of crowdfunding. This is because the platform involves the channeling of uncollateralized capitals to finance a particular business through the internet with no intermediary like a bank 
(Hossain, \& Oparaocha, 2017). The issue of trust and transparency in Nigeria is not a mere thing. In a study conducted by Okoyeuzu, et al., (2019), it was discovered that most of the respondent stressed the significance of trust because there is a very big considerable issue among many Nigerian when it comes to trusting each other. Therefore, they prefer using social media like Facebook, Twitter, and mostly Instagram to solicit for funds.

Furthermore, It appears challenging for crowdfunding to break into the financial market which has been dominated by the customary mainstream means of financing. This is mostly accurate in the case of trust whereby mainstream financial institution has already deeprooted its influence and reputation for a long time in the market. This showed that the users are acquainted and have assurance in their product. However, according to Kang, Gao, Wang, and Zheng (2016), trust can be established between the investors and the fundraiser from the perspective of calculus and relationship. Furthermore, Nor and Hashim (2020), discovered that the religiosity of the key players can contribute to trust as well. In that regard, crowdfunding platforms can correct this. To conduct this, each crowdfunding should demonstrate its trustworthiness and reliability to investors by displaying security features on their site as well as certificates of funds given stipulated terms and conditions should be stated.

\section{Issue of Double Taxation}

The tax rules should also expect corrections to think about the investors and entrepreneurs, in any case, there is a premonition peril for twofold tax assessment that can be charged on crowdfunding. This is because of stamp obligations and capital additions charges, which are deductible upon asset transfer. According to World Bank (2013); and Okoyeuzu et al., (2019), it was reported that one of the prominent challenges facing entrepreneurs in Nigeria is the high tax rate. For crowdfunding to develop in a developing country, the tax system should be flexible concerning new projects (Amuna et al., 2017). However, The Federal Government of Nigeria may consider providing special tax waivers and incentives for securities issued through the platforms by SEMs. This includes exemption of such securities from the tax imposed under the Companies Income Tax Act. Such policies may further encourage eligible issuers to undertake such crowdfunding transactions (Numa, 2019).

Finally, to preserve the reliability and good principles of crowdfunding, this study argues that it is necessary to build a framework of top practices through the three pillar method.

Regulation pillar; while waiting for regulation to be legislated, crowdfunding mediators should provide criteria centering around the subsequent sorts of consumer safety. These include financial and operational transparency practices, security of data and payments, financial control, platform performance, and operational processes to protect and detect fraud. 
Education pillar; for the assurance enhancement of crowdfunding, it is presumed that there is a necessity for educational settings to educate funders, entrepreneurs, and stakeholders on the advantages of the institution, and the various types. These settings will be responsible for a just and reasonable guide to safeguard the economic interest, diversification, and exposure of investors and investees over various crowdfunding models. Furthermore, it helps to offer management about fraud, risk clarifications and possibly testing the knowledge of investors.

Research pillar; it is presumed that the crowdfunding industry should inspire educational and intermediary study. The workers should make data sets available to promote industry requests of discovering an open and transparent method. Furthermore, studies and public reports will bring about improvement and competition within the industry.

\section{CONCLUSION}

Crowdfunding is an alternative funding option that has been thriving across the globe for the last decade with the help of the internet. In addition, it supports society's contribution to growing businesses and provides remarkable flexibility for entrepreneurs to solicit for funds. Interestingly, Nigeria as a country that has a huge size of population and developmental chances has the potential of becoming the hub center of crowdfunding in Africa. However, various challenges are facing the growth of the platform as a means of financing. These include issues of regulation, lack of adequate awareness, lack of sufficient understanding, as well as fraud and corruption, which is prevalent in the country. Meanwhile, the efforts of the SEC are commended and highly praised to have initiated the procedure of regulating the crowdfunding industry. It was stated that the industry should not be excessively regulated since people's involvement may be discouraged. Likewise, there is a need for greater public awareness about crowdfunding and the establishment of a supporting environment for the working of the system. Also, there is a crucial need for educating the people on the concept of crowdfunding and its role in facilitating business projects with substantial funding. Finally, this is a conceptual study without empirical analysis. Therefore, future studies with empirical analysis should be conducted to explore crowdfunding in Nigeria.

\section{BIBLIOGRAPHY}

Abdullah, A. (2016). Crowdfunding as An Emerging Fundraising Tool: With Special Reference to the Malaysian Regulatory Framework. Islam and Civilisational Renewal, 7(1), 98-119.

Achsien, I. H., \& Purnamasari, D. L. (2016). Islamic Crowdfunding as the Next Financial Innovation in Islamic Finance: Potential and Anticipated Regulation in Indonesia. European Journal of Islamic Finance, 5. 1-10. https://doi.org/10.13135/24212172/ 1771. 
Aderemi, A. M. R., \& Ishak, M. S. I. (2020a). Adopting Qard Al-Hasan and Mudarabah Crowdfunding for Micro Enterprise. International Journal of Islamic Economics and Finance Research, 3(2), 26-38.

Aderemi, A. M. R., \& Ishak, M. S. I. (2020b). Crowdfunding as An Alternative Mode of Financing for Micro and Small Enterprises: A Proposed Qard-al-Hasan Contract. International Journal of Islamic Economics and Finance (IJIEF), 3(3), 95-118. https://doi.org/10.18196/ijief.3235.

Afrikstart. (2015). Crowdfunding in Africa; Fundraising Goes Digital in Africa: The emergence of Africa-Based crowdfunding platforms. Retrieved from www.afrikstart.com.

Amuna, Y. M. A., Al Shobaki, M. J., Naser, S. S. A., \& El Talla, S. A. (2017). Crowdfunding as One of the Recent Trends in Financing Emerging and Small Projects in the Arab World. International Journal of Business Engineering and Management Systems, 1, 116.

Augustine, A. A. (2019). Crowdfunding and SMEs Financing in Nigeria- Threat and Opportunities. International Journal of Development Research, 09(09), 30091-30100.

Berndt, A., \& Mbassana, M. (2016). Crowdfunding: The Beliefs of Rwandan Entrepreneurs. East Africa Research Papers in Business, Entrepreneurship and Management. EARPBEMNo. 2016:05.

Bolu, I. (2016). Crowdfunding in Nigeria. Pulse Newspaper. Retrieved from www.spaajibade.com.

CrowdfundInsider. (2017). Report: Crowdfunding Potential in Nigeria. Retrieved from https://Www.Crowdfundinsider.Com/2017/04/98697-Report-CrowdfundingPotential-Nigeria/.

Gabison, G. A. (2015). Understanding Crowdfunding and its Regulations. How can Crowdfunding help ICT Innovation? In European Commission Joint Research Centre. https://doi.org/10.2791/562757

Hendratmi, A., Sukmaningrum, P. S., Ryandono, M. N. H, \& Ratnasari, R. T. (2019). The Role of Islamic Crowdfunding Mechanisms in Business and Business Development. Global J. Bus. Soc. Sci. Review, 7(1), 1-7.

Hollander, M. A. G., \& Greene, M. G. (2015). A Conceptual Framework for Understanding Crowdfunding. Communications of the Association for Information Systems, 37(1), 1.

Hossain, M., \& Oparaocha, G. O. (2017). Crowdfunding: Motives, Definitions, Typology and Ethical Challenges. Entrepreneurship Research Journal, 7(2). 1-27. https://doi.org/ 10.1515/erj-2015-0045. 
Ibrahim, U. (2019). The Impact of Cybercrime on the Nigerian Economy and Banking System. NDIC Quarterly, 34(12). 1-20.

Ishak, M. S. I., Kamaruddin, M. H., \& Aderemi, A. M. R. (2021). Mudharabah Based Crowdfunding as An Alternative Source of Funding Book Publications in Malaysia. Journal of Islamic Marketing. https://doi.org/10.1108/JIMA-05-2020-0147.

Ishak, M. S. I., \& Rahman, M. H. (2021). Equity-based Islamic Crowdfunding in Malaysia: A Potential Application for Mudharabah. Qualitative Research in Financial Markets. https://doi.org/10.1108/QRFM-03-2020-0024.

IWS. (2019). Internet World Stats, Usage and Population Statistics. Retrieved from https://www.Internetworldstats.Com/Africa.Htm\#ng.

Kang, M., Gao, Y., Wang, T., \& Zheng, H. (2016). Understanding the Determinants of Funders' Investment Intentions on Crowdfunding Platforms: A Trust-based Perspective. Industrial Management \& Data Systems, 116(8), 1800-1819.

Kazaure, M. A., \& Abdullah, A. R. (2018). Crowdfunding as Financial Option for Small and Medium Enterprises (SMEs) in Nigeria. Pertanika Journal of Scholarly Research Reviews, 4(3), 89-96.

Lawal, K. B. (2019). Prospects and Challenges of Crowdfunding Financing Models for Housing Delivery in Lagos, Nigeria. Available at SSRN:https://ssrn.com/abstract= 3500107.1-16. http://dx.doi.org/10.2139/ssrn.3500107.

Massolution. (2012). Crowdfunding Industry Report. 1-30. Retrieved From http:/ncfacanada.org/wp-content/uploads/2012/10/Massolution-Full-IndustryReport.pdf.

Massolution. (2015). Crowdfunding Industry Report. 1-118. Retrieved From https://www.smv.gob.pe/Biblioteca/temp/catalogacion/C8789.pdf.

Meric, J., Maque, I., \& Brabet, J. (2016). International Perspectives on Crowdfunding. Emerald Group Publishing Limited. 257-263. https://doi.org/10.1108/978-1-78560315-020151026.

Mollick, E. (2014). The Dynamics of Crowdfunding: An Exploratory Study. Journal of Business Venturing, 29(1), 1-16. https://doi.org/10.1016/j.jbusvent.2013.06.005.

Nor, S. M., \& Hashim, N. A. (2020). Trust Motivates Funders to Participate in Shari'ah Crowdfunding. Malaysian Journal of Society and Space, 16(2), 228-238. https://doi.org/10.17576/geo-2020-1602-18.

Numa, T. (2019). Modern Technology Meets Capital Raising - Cool Cash for Small Businesses. Retrieved from www.acedemia.edu. 
Oguama, L. (2020). Fintech Credit Market - Crowdfunding: An Evaluation of Market Models. Available at SSRNElectronic Journal 3696044., 1-13.

Okoyeuzu, C., Nwakoby, I., \& Onwujekwe, O. (2019). Crowdfunding: An Alternative to Funding Women Entrepreneurs. South Asian Journal of Social Studies and Economics, 5(2), 1-10. https://doi.org/10.9734/sajsse/2019/v5i230140

Ordanini, A., Miceli, L., Pizzetti, M., \& Parasuraman, A. (2011). Crowd-funding: Transforming Customers into Investors through Innovative Service Platforms. Journal of Service Management, 22(4), 443-470.

Renwick, M. J., \& Mossialos, E. (2017). Crowdfunding Our Health: Economic Risks and Benefits. Social Science and Medicine, 191, 48-56. https://doi.org/10.1016/j. socscimed.2017.08.035.

Schwienbacher, A., \& Larralde, B. (2012). Crowdfunding of small Entrepreneurial Ventures. SSRN Electronic Journal, 10. 1-23. http://dx.doi.org/10.2139/ssrn.1699183.

SEC Nigeria. (2020). Exposure of Proposed New Rules to the Rules and Regulations of the Commission. Retrieved from https://sec.gov.ng/category/press-release/.

Soreh, W. C. (2017). Awareness and Attitude Towards Crowdfunding in Nigeria. International Journal of African and Asian Studies, 36, 1-8.

Thaker, M. A. M. T., Mohammed, M. O., Duasa, J., \& Abdullah, M. A. (2016). The Behavioral Intention of Micro Enterprises to Use the Integrated Cash Waqf Micro Enterprise Investment (ICWME-I) Model as A Source of Financing. Gadjah Mada International Journal of Business, 18(2), 111-130.

Thaker, M. A. M. T., Thaker, H. M. T., \& Pitchay, A. A. (2018). Modeling Crowdfunders' Behavioral Intention to Adopt the Crowdfunding-Waqf Model (CWM) in Malaysia: the Theory of the Technology Acceptance Model. International Journal of Islamic and Middle Eastern Finance and Management., 11(2), 231-249.

The Guardian. (2017). Nigeria and Internet Fraud. Retrieved From www.guardian.ng.

Valančienè, L., \& Jegelevičiūtė, S. (2014). Crowdfunding for Creating Value: Stakeholder Approach. Procedia - Social and Behavioral Sciences, 156(April), 599-604. https://doi.org/10.1016/j.sbspro.2014.11.248.

Wahjono, S. I., Marina, A., \& Widayat. (2015). Islamic Crowdfunding: Alternative Funding Solution. $1^{\text {st }}$ World Islamic Social Science Congress (WISSC), Malaysia. 1-12.

Wilson, K. E., \& Testoni, M. (2014). Improving the Role of Equity Crowdfunding in Europe's Capital Markets. SSRNElectronic Journal. http://dx.doi.org/10.2139/ssrn.2502280.

World Bank. (2013). Crowdfunding's Potential for the Developing World. Washington D. C: InfoDev. Finance and Private Sector Development Department. 